\title{
THE LEGALITY OF SO-CALLED "BUSINESS INSURANCE"
}

In view of the comparatively modern but increasingly common practice of writing insurance for the benefit of those who maintain towards one another a business relationship, whether as between a corporation and its officers or stockholders, debtor and creditor, or copartners, the subject of the legality of such insurance and the advantages which may be derived therefrom becomes of great interest to the business world.

In a striking article contributed to the "Life Association News" for November, I9I4, Mr. Charles W. Scovel says:

"Business insurance is as yet a new idea to most business men. By its novel uses it interests at once many who are 'not in the market' when approached for personal insurance. It is spreading like wildfire. Scores of millions have been, written during the last few years. Big corporations have been taking amounts ranging as high as $\$ I, 500,000$ on a single officer."

The first question which presents itself to the mind is whether such insurance is valid, whether in such cases that insurable interest which the law requires exists. The general principle is stated by a prominent text writer as follows: ${ }^{1}$

"A person may procure insurance on the life of another when he is so related to that other by reason of blood, marriage, or commerce that he has well grounded expectations of deriving benefit from the continuation of that other's life, or of suffering detriment or incurring liability through its termination" (p. I25).

"Commercial Relations. Any person is permitted to protect by insurance any commercial interest he may possess in the life of another. A creditor may insure the life of his debtor, a partner that of his copartner, or a servant the life of his master. And a master may insure his servant against such injuries in the course of his employment as will impose liability on the master. The life of a contractor under obligation to construct any work may be insured by his employer, and persons pecuniarily interested in any financial enterprise may insure the life of the financier who has charge of it. The

\footnotetext{
${ }^{1}$ Vance On Insurance.
} 
life of one only indirectly connected with a commercial enterprise may be insured by those involved in it if the death of such person would injuriously affect the enterprise, as in the recent instances of insurance on the life of the King of England procured by those who had invested money in preparations for the King's coronation. So a tenant per autre vie might well insure the life of his cestui que vie; and one who owns a property interest contingent upon another's attaining some specified age may through insurance secure indemnity for the loss he would suffer by the death of that other before arriving at that age. A surety may insure the life of his principal, for the latter is but a conditional debtor, but the principal has no such interest in the life of his surety. Likewise it has been held that a building association has no insurable interest in the life of a member who is in no wise indebted to it."

\section{Corporation Insurance.}

The paucity of authority on the question of the validity of insurance taken out by a corporation on the lives of its officers, stockholders or employees is surprising. An examination of the books on the subject of insurance will disclose that works as modern as Cyc., The American and English Encyclopedia of Law, Cooley's Briefs On the Law of Insurance, and Vance On Insurance contain no mention of such insurance.

Nevertheless, such insurance is believed to be valid, not only as answering a patent business need but as coming well within that rule of law which requires an insurable interest. A painstaking examination of the authorities has brought to light only a few cases dealing with this subject. Because of the smallness of the number of cases and their importance, it is proposed to examine them separately and in chronological order.

The earliest decision was the case of Trinity College $v$. Travelers' Insurance Company. ${ }^{2}$ Trinity College was supported by the Methodist Church. It procured an individual member of such church to insure his life for its benefit, itself paid all the premiums, including the first, and received the policy. It was not shown that the insured himself had ever given the college anything or that he was likely to. Under such circumstances, it was very properly held that the college had no insurable interest, though some of the language of the opinion is much too broad.

\footnotetext{
${ }^{2}$ II3 N. C. 244, I8 S. E. I75 (decided Oct. 3I, I893).
} 
The next decision was by the Virginia Court of Appeals in the case of Tate $v$. Commercial Building Association. ${ }^{3}$ In this case a building association was held to have no insurable interest in the life of a stockholder not indebted to it. It was not shown that the stockholder was an officer of the association or actively engaged in promoting its business. Nor did it appear that his connection with the association in any way improved its credit. The bare question was presented as to whether his mere status as a stockholder gave to the association an insurable interest in his life. It was decided that it did not.

The present opinion of the Virginia Court on this question of business insurance is shown by the decision in Mutual Life Ins. Co. v. Board, infra.

Four years later the New Hampshire Supreme Court had the problem presented to it in the case of Mechanics' National Bank v. Comins. ${ }^{4}$ Here a bank was a heavy creditor of the George T. Comins Company (presumably a corporation). One George T. Comins was its manager. He took out a policy on his life and assigned same to the bank. The court, as to its decision on this point, proceeded on the theory that the policy was taken out for the purpose of assignment and was, therefore, invalid unless the bank had an insurable interest in the life of the insured. The question was thus presented as to whether one having no interest in a corporation, other than an indebtedness owed him by such corporation, can insure the life of the manager of such corporation. It was held that such insurance was valid. The court uses the following language:

"It is hardly necessary to say that the success of a corporate enterprise may be so interwoven with the personality of its manager that its stock is taken, and money is loaned to carry it on, as much in reliance upon that personality as upon the intrinsic merit of the enterprise; and no reason appears why a stockholder or creditor, the value of whose investment may be reasonably said to depend upon the life or health of the man at the helm, should not have an insurable interest in his life, the same as one who invests money in a partnership, relying upon the skill or experience of his copartner, has an insurable interest in the life of the latter, or one who equips a mining expedition has an insurable interest in the life

${ }^{3} 97$ Va. 74, 33 S. E. 382, 45 L. R. A. 243, 75 Am. St. Rep. 770 (decided Apr. 6, I899).

' 72 N. H. I2, 55 Atl. I9I, IOI Am. St. Rep. 650 (decided in Jan., I903). 
of him to whom its management is committed. The creditor or stockholder, under such circumstances, would seem to have that 'reasonable expectation of pecuniary, benefit or profit from the continuance of another's life' which is held sufficient to constitute an insurable interest. In such case 'the essential thing . . . that the policy should be obtained in good faith, and not for the purpose of speculating upon the hazards of life' would appear to be present. 'In this view we are not prepared to say, as matter of law, . . . that the plaintiffs, who were furnishing the funds to carry on the business of the George $T$. Comins Company, had no insurable interest in the life of George $\mathrm{T}$. Comins, the manager, and apparently the originating and directing personality in the enterprise. ${ }^{5}$

The next case, Victor $v$. Louise Cotton Mills, ${ }^{6}$ arose in North Carolina. One Wilson was the president of a cotton mill. $\mathrm{He}$ was a manufacturer and financier of great capacity, skill and ability. His services to the cotton mill of which he was president were conceded to be of great and peculiar value, and such services as could be performed by him only. Wilson insured his life in favor of the cotton mill for $\$ 100,000$ and assigned the policies to the mill, which paid the first and all subsequent premiums thereon. Afterwards the said Wilson severed his connection with the mill company, but said company continued to keep the policies of insurance in force. One of the stockholders of the cotton mill, being discontented with the large premiums which the company was continuing to pay, and fearing that the policy was invalid, brought suit to enjoin the cotton mill from paying any further premiums on the policy. The court, without deciding the question of insurable interest, held that the continued payment of the premiums after Wilson had severed his connection with the mill was ultra vires, and enjoined it from continuing to pay the premiums. Great stress was laid on the fact that Wilson was no longer connected with the mill. The

'In a note written in 1908 , in $I 6 \mathrm{~L}$. R. A. (N. S.), I020, the above case is commented on as follows: "The statements in the foregoing case in regard to stockholders are dicta, as the person seeking to collect the insurance was a creditor, and not a stockholder. But if that view of the law is correct, it would seem that a corporation would also have an insurable interest in the life of an important officer, as the interest of the corporation would be no more remote than that of a stockholder, and certainly would be greater in extent."

${ }^{6} 148$ N. C. 107,6 I S. E. 648 , 16 L. R. A. (N. S.) I020, I6 Ann. Cases, 29I (decided May 29, Ig08). 
language of the court, however, indicates that it considered such insurance bad business policy anyway. This case was decided on general principles, the court admitting that neither the court nor counsel had been able to find a case in point.

This case might seem not to militate against the view that such insurance is valid so long as the insured official retains his connection with the corporation. But in the case of Victor $v$. Chadwick Mfg. Company, ${ }^{7}$ decided on the same day as the Louise Cotton Mills Case, the fact was that the insured still retained his office and was the president of the defendant manufacturing corporation, and yet the court held such insurance to be ultra vires, and said "this fact does not affect the result."

${ }^{7}$ I48 N. C. II9, 6I S. E. 653.

'In a note to Victor $v$. Louise Cotton Mills, supra, written in I908, in I6 L. R. A. (N. S.), ro20, it is said by the annotator: "There appears to be no other reported case involving the power of a corporation to pay with corporate funds the premiums on a life insurance policy carried on the life of one of its officers for the benefit of the corporation. In the foregoing case the relations between the officer whose life had been insured and the corporation had been severed, and although the court plainly implied that it did not believe the fact would make any difference, yet it is quite possible that such a distinction might be made were the case to come up in the other form in another court." He also says: "Nor does there appear to be any other reported case which directly passes upon the question whether a corporation has an insurable interest in the life of its president or any other of its officers."

This Cotton Mills Case is also annotated in 16 Ann. Cases, 295. This note was written in Igro. This annotator says: "A careful search discloses but few cases passing upon the right of a corporation to insure the lives of its officers."

He then cites Victor v. Chadwick Mfg. Co., supra, Mechanics' Nat. Bank v. Comins, supra, Tate v. Bldg. Ass'n., supra, and Trinity College v. Travelers' Ins. Co., supra. The only new case he cites is one decided in Igos by an Ohio Circuit Court. He comments on this as follows: "It has been held that a corporation organized for the purpose of manufacturing cooperage has no right to give its promissory note for the purpose of carrying insurance on the lives of its directors. Security Mut. L. Ins. Co. v. J. M. Schott, etc., Co., 3 Ohio Cir. Ct. Rep. 656, affirming I9 Ohio Dec. 249, wherein it was said: 'The insurant under each of the five policies was not indebted to the company, and under no obligation to it other than as stockholder, director or manager. The company was not investing surplus funds, but was incurring an obligation through its secretary and manager, without the assent of the board of directors, for the purpose of securing a policy of insurance for five thousand dollars on each of five directors, an object wholly foreign to its incorporation. While it is true, as suggested by counsel, that each 
But the Supreme Court of Ohio, in the subsequent case of Keckley v. Coshocton Glass Company, ${ }^{9}$ reaches a different conclusion. That case was as follows:

Thomas J. Gainor was employed (in what capacity does not appear) by, and was a large stockholder in. The Coshocton Glass Company, a corporation. By reason of his skill and experience, he was largely relied upon to make the business of the corporation a success. In establishing itself in business the company was a large borrower of money and it also sold preferred stock to raise working capital. In order to secure against loss or failure of the enterprise and to maintain the credit of the company, Gainor took out a policy of insurance on his own life payable to the company, the policy was delivered to the company, and the company paid the first and all subsequent premiums on the policy. Gainor represented to creditors of the glass company and to banks from which he was seeking to and did procure loans for said company, and to persons whom he sought to induce and did induce to become purchasers of stock in said company, that this policy of insurance belonged to and was assets of said glass company. Before Gainor's death he sold his stock and severed all connection with the glass company. On his death his executors and the glass company both claimed the insurance, the former on the ground that the company had no insurable interest in Gainor's life. The insurance company paid the money into court. The court awarded the money to the glass company, holding: (I) It did have an insurable interest in Gainor's life. On this point the court said: "It thus distinctly appearing that the company had a direct pecuniary interest in the life and personal services of Gainor, the insurance for the benefit of the company was based on an insurable interest and was valid"; (2) That the policy, being valid when issued, did not lapse when Gainor severed his connections with said company; a life insurance contract is not a mere contract of indemnity "but is a contract to pay to the beneficiary a certain sum of money in the event of

insurant might have taken out a policy, paid the premium, and made the corporation the beneficiary, yet in this case the applicant incurs no liability, and it is expressly agreed that the corporation shall pay all premiums, and did execute and deliver its note for the first two annual premiums. We think that the company had no insurable interest in its directors, and if it did that the secretary and manager was unauthorized to enter into the contract without the assent of the board of directors."

'86 Oh. St. 2r3, 99 N. E. 299, 29 Ann. Cases, 607 (decided June 5, 1912). 
death"; (3) That even if the company had no insurable interest "there is abundant authority for holding that when the insurer has recognized the validity of the policy by paying the amount of the policy to the beneficiary, or into court, other parties claiming an interest in the fund cannot object on the ground that the beneficiary named in the policy had no insurable interest."

The latest decision seems to have been that of the Virginia Supreme Court in the case of Mutual Life Ins. Co. v. Board, ${ }^{10}$ decided January I5, I9I4. In that case one B. F. Board was the principal incorporator, president and general manager of the Board, Armstrong \& Company Corporation, a Virginia corporation. He procured from the Mutual Life Ins. Company of New York a policy on his life, payable to the corporation. Both the application and the policy stated that the interest of the beneficiary in the insured was "loss of services in the event of death." The company paid the first premium. On Board's death the insurance company contested the payment of the policy on the ground of a lack of insurable interest in the corporation, and because the contract on the part of the corporation was ultra vires. The court overruled both of these objections, holding that the contract of insurance was not ultra vires, and that the corporation had an insurable interest in Board's life. In passing on the question of ultra vires, nothing is said about the North Carolina cases, and the court decides the question of insurable interest mainly from general principles and business policy, though Mechanics Nat. Bank v. Comins, supra, and Keckley v. Coshocton Glass Co., supra, are quoted from at length and approved. In reaching its conclusion, the court says:

"The deceased was the president and manager of the corporation, and had been since its organization. His relation to and knowledge of the financial and manufacturing interests of the plaintiff was such that his death could not fail to result in serious and substantial loss to its creditors and all others interested in its prosperity. Although it is well known that the leading insurance companies of the country solicit and carry the class of insurance here involved, we have been unable to find any decision directly in point. The principles, however, announced by the decisions and stated by the text-writers we think clearly show that the plaintiff had an insurable interest in the life of B. F. Board, its president and general manager."

\footnotetext{
${ }^{10}$ II5 Va. 836,80 S. E. 565 .
} 
In the companion case of Mutual Life Ins. Co. of New York v. Board Motor Truck Company Corporation, decided on the same date, and reported with the case just commented on, a similar conclusion is reached by the Virginia court.

It is believed that the true rule on this subject is the one announced by the Virginia court in the cases last mentioned, and that it is entirely legitimate for a corporation to take out insurance on the lives of its officers or employees in every case where the death of such officer or employee would probably cause a financial loss. This view is certainly consonant with the general rule of the law of insurance as to what constitutes an insurable interest. It is further believed that such contracts on the part of a corporation are not ultra vires. It was so held expressly by the Virginia court, in the cases above cited, and the case from Ohio is implied authority for the same proposition, inasmuch as no question seems to have existed in the mind of the court on this proposition. North Carolina is the only court, so far, holding the contrary doctrine.

The business considerations rendering such insurance desirable, and the practical benefits derived from it by a corporation, are fully shown in the article by Mr. Scovel, above mentioned. He condenses an elaborate argument as to the benefits to be derived from such insurance into the following summary:

"Business life insurance renders six services. During life, it (I) immediately fortifies financial standing, and (2) gradually builds up emergency cash. At death, it supplies spot cash as indemnity (3) for direct loss, and (4) for consequential damage; and spot cash to help (5) in replacing the dead man, and (6) in readjusting everything to the new conditions. And the bulk of the premiums is not money spent, but money laid aside."

These business considerations, combined with the tremendous use being made of it now by corporations, are strong practical reasons for upholding its validity, and will doubtless have much influence with the courts.

\section{Creditors' Insurance.}

Such insurance may take three forms:

(a) The creditor may himself take out the policy on the debtor's life;

(b) The debtor, in pursuance of an agreement with the creditor who pays the premiums, may take a policy on his own life and assign it to the creditor; 
(c) The debtor, having a valid policy on his own life taken out for his own benefit, may assign same to the creditor as collateral security; or he may assign absolutely, or sell, such policy to the creditor, or to anyone else.

Where a creditor takes out insurance on his debtor's life, or a debtor, in pursuance of an agreement with the creditor who pays the premiums, takes a policy on his own life and assigns it to the creditor, the transaction in both cases is held valid, because the creditor has an insurable interest in the debtor's life.

But there exists a conflict in the decisions as to how much of the proceeds of the policy the creditor is entitled to keep in such cases. One view, and it is thought the better in point of reason, treats such proceeds as belonging entirely to the creditor, and this even though the debt has been paid in full before the death of the insured. This is on the theory that a policy valid when issued continues valid, although the insurable interest may thereafter cease. The other view, and this view seems to be sustained by the weight of authority, holds that the creditor in such cases can retain the proceeds only to the extent of the debt and such advancements as are subsequently made in pursuance of the assignment, together with any expenses incurred on account of the policy itself by the creditor. These cases proceed on the theory of indemnity. ${ }^{11}$

Of course, where the debtor simply assigns to the creditor his policy as collateral security the creditor has a right to be reimbursed his debt, with interest and expenses, and nothing more. ${ }^{12}$

But where the debtor assigns absolutely his own valid policy to a creditor, that is he sells it to him, the latter may keep it alive and recover the full amount of the policy, irrespective of the debt. ${ }^{13}$

\footnotetext{
II Vance On Insurance, pp. 127, 410-412. This writer favors the minority rule, and cites as sustaining it the courts of England, Indiana, New York, Pennsylvania and Vermont. In a note in 22 Anno. Cases, 653, the courts sustaining the majority rule are said to be those of the United States, California, Georgia, Kentucky, Massachusetts, Michigan, New Hampshire, New York, Tennessee, Texas, Utah, Virginia, and Canada; those sustaining the minority rule, Louisiana and Maryland.

${ }^{12} 3$ Am. \& Eng. Encl. Law, p. 952; Vance On Insurance, pp. 412-413.

${ }^{23} 3$ Am. \& Eng. Encl. Law, p. 952; Vance On Insurance, pp. 412-4I3; Grigsby v. Russell, 222 U. S. I49, 32 Sup. Ct. 58.
} 
And this last proposition is true whether the policy be assigned to the creditor or to any other person, for it is held by the great weight of authority that a policy of life insurance, taken out in good faith and valid in its inception, may be thereafter freely assigned to anyone, whether the assignee have an insurable interest or not.14

The Virginia Court, among others, for some time seemed to be committed to the doctrine that it was just as necessary for an assignee of a valid policy to have an insurable interest as it would have been had such assignee originally sought himself to take out such insurance on another's life. ${ }^{15}$ But the question is now settled by statute in Virginia in favor of the doctrine above stated $^{16}$ and the trend of decision even in those states which originally held to the contrary doctrine is to reverse their holdings and gef in line with the great majority of the decisions. ${ }^{17}$

\section{Partnership Insurance. ${ }^{18}$}

This form of insurance in this country seems to have had its origin in the days of the California gold fever. It was then common for a person who remained in the east to send an argonaut into California, equip him, advance him money, agree for a share in any possible discoveries of gold, and then, to make himself safe, take out insurance on the prospector's life. ${ }^{19}$

The leading case on the right of a partner to insure the life of his copartner is Connecticut Mut. Life Ins. Co. v. Luchs. ${ }^{20}$ In this case the Supreme Court of the United States, in holding that one partner had an insurable interest in the life of the other, said:

"Certainly Luchs had a pecuniary interest in the life of Dillenberg on two grounds: because he was his creditor and because he was his partner. The continuance

\footnotetext{
${ }^{14}$ Vance On Insurance, I40-I44; Note in 27 Anno. Cases, 864; Grigsby v. Russell, supra.

${ }^{15}$ Roller v. Moore's Adm'r., 86 Va. 5I2, to S. E. 24I; Tate v. Commercial Bldg. Ass'n., 97 Va. 74, 33 S. E. 382.

${ }^{16}$ Code of Va. \$2859a.

${ }^{17}$ Hardy v. Aetna Life Ins. Co., I52 N. C. 286,67 S. E. 767.

${ }^{18}$ The general rule as to such insurance is stated in the quotation made from Vance On Insurance, supra.

${ }^{10}$ Morrell v. Trenton $M$. L. \& F. Ins. Co., to Cush. (Mass.) 282, 57 Am. Dec. 92; Trenton M. L. \& F. Ins. Co. v. Johnson, 24 N. J. I. 576; Bevin v. Conn. Mut. Life Ins. Co., 23 Conn. 244.

${ }^{20}$ I08 U. S. 498, 27 L. Ed. 800, 2 Sup. Ct. 949 (decided in I883).
} 
of the partnership, and, of course, a continuance of Dillenberg's life, furnished a reasonable expectation of advantage to himself. It was in the expectation of such advantage that the partnership was formed, and, of course, for the like expectation, was continued."

It is at the present day well settled that the partnership relation gives to a copartner, or to the partnership itself, an insurable interest in the life of any one of the individual partners, though there are not as many cases as one would expect on the subject.21

In the recent case of Rahdus, Merrett \& Hagler v. Peoples Bank, ${ }^{22}$ a partnership of three were conducting business. The lives of the several members were insured by the copartnership, for the benefit of the firm, in the sum of $\$ 5000$ on the life of each partner. All of the premiums on the policies taken out on the lives of the members were paid by the partnership as an expense of its business, and the policies so taken out were delivered to and kept in the possession of the partnership. Later on this partnership incorporated, and the policies were assigned by the partnership to the corporation, which later paid one premium. One of the partners died, and a contest arose between his administrator and the corporation as to who should get the proceeds of the policy. The administrator contended that there was no insurable interest in the two other members of the partnership at the time that the policies were issued and that, if there was an insurable interest, it became extinguished on the formation of the corporation. Both of these contentions were overruled by the court, and the proceeds awarded to the corporation. The court says: "Each member of a copartnership certainly has an interest in the continuance of the lives of his copartners, growing out of the partnership relation. The necessities of the business incur more or less liability, which might be serious financially if one were removed by death." As to the administrator's second contention, it was held that the assignment to the corporation was valid..$^{22}$

An interesting view of partnership insurance was announced in Texas in the case of Cheeves $v$. Anders. ${ }^{23}$ There a partner-

\footnotetext{
${ }^{21} 25$ Cyc. 706, 707; 3 Am. \& Eng. Encl. Law, 955; Note in 22 Anno. Cases, 299.

${ }^{22}$ II3 Minn. 496, I30 N. W. I6. For an instructive case in harmony with the above see Rush v. Howkins, 135 Ga. 128, 68 S. E. ro35 (decided Sept. 22, I9I0).

${ }^{23} 87$ Tex. 287,28 S. W. 274 (decided Nov., I894).
} 
ship consisting of two partners took out a $\$ 10,000$ policy of insurance on the life of each partner, payable to the firm. The premiums were paid by the firm. Before the death of either partner, the firm was dissolved, one of the partners taking over all firm assets and assuming all firm liabilities. After such dissolution the outgoing partner died, and a contest for the insurance arose between his administrator and the surviving partner. It was held that the policy was originally valid, but that the insurable interest of the partner who continued the business ceased upon the dissolution of the partnership, and he should be allowed to recover only the premiums paid by the firm, the administrator of the deceased partner getting the residue.

This case is against the weight of authority as to the last proposition. It is settled law in a great majority of the states that an insurable interest need only exist at the time of the taking out of a life policy, and that a subsequent loss of such interest on the part of the beneficiary does not invalidate the policy. If it were held that a partner had an insurable interest in his copartners only while he occupied the position of creditor, and that the insurance was solely allowed on the theory of creditor's insurance, then the case would be in line with those decisions which refuse to allow a creditor to collect any more insurance money than will indemnify him. But it is thought that the insurable interest of a partner rests on other considerations, and that the general rule that if such insurance is valid when taken out it is valid always should be held to apply. These creditor's cases rest on the mistaken theory that a policy of life insurance is merely a contract of indemnity, ${ }^{24}$ and, even where this rule obtains, it should be confined to its own narrow limits. Certainly this is true if the rule announced by the Supreme Court of the United States be correct, that a woman who obtains a policy on her husband's life does not lose its benefit and may collect the insurance even though she be afterwards divorced from her husband and marries another man. ${ }^{25}$

The only State not adopting the rule as stated appears to be North Carolina. It was there held that "under certain conditions a partner has an insurable interest in the life of his copartner." But in the later case of Powell v. Mutual Benefit

${ }^{24}$ See Vance On Insurance, pp. I27, 4IO.

${ }^{25}$ Connecticut Mutual Life Ins. Co. v. Schaffer, 94 U. S. 457,24 L. Ed. $25 \mathrm{x}$.

${ }^{20}$ Trinity College v. Ins. Co., II3 N. C. 244 , I8 S. E. I75. 
Life Insurance Co., ${ }^{27}$ this was admitted to be true only where the relation of debtor and creditor existed, and the court decided that the mere partnership relation, without a showing that the insured partner was indebted to the other or was to furnish any labor, skilled or otherwise, as his contribution in lieu of money, did not in itself constitute an insurable interest.

This Powell Case has been overruled in so far as it held that a life policy could only be assigned to one having an insurable interest, ${ }^{28}$ and it may be that if the question were again presented to the North Carolina Court it would follow the general rule and make the decisions unanimous.

\section{Forms Which Such Insurance May Take.}

Such partnership insurance may be taken out in several different ways. Suppose there is a partnership consisting of A, B, and $C$, under the firm name of $A$ \& Company. Each partner might insure his life for the benefit of the firm, the firm paying the premiums ${ }^{22}$ or each might insure his life for the benefit of the other two, the firm paying the premiums. ${ }^{23}$ By the first method the insurance money, when collected, would be firm asseț, would be administered like any other firm assets, and the executor or administrator of the deceased partner would come in for his share of the insurance on an accounting just as he would on any other assets. There would be no injustice here, however, as it must be remembered that the deceased partner had his interest in the premiums which the firm paid. By the second method the proceeds of the policy would go to the surviving partners individually and would not be firm assets

\section{Consent Of The Iife Insured.}

It seems well to call attention here to a matter which seems to be often overlooked, namely, that when one man insures another's life the consent of the one whose life is insured should be held to be a prerequisite on grounds of public policy. A large practice has grown up to the contrary, and there is little direct authority on the point. The law has been stated as follows:

"While the practice of insurers makes the question somewhat uncertain, it seems that both by reason and

${ }^{2 \pi}$ I23 N. C. I03, 3I S. E. 38I, 68 Am. St. Rep. 8I8.

${ }^{28}$ Hardy v. Aetna Life Ins. Co., r52 N. C. 286,67 S. E. 767. 
authority insurance written upon the life of one who has not consented thereto is contrary to public policy and void.' 20

\section{The Reasons Why Such Insurance Is Desirable.}

The practical arguments in favor of the validity of corporation insurance are forceably set forth by Mr. Charles W. Scovel in his article referred to above. What the courts have said on the subject of the desirability of such insurance is shown in the quotations made above where the legality of such insurance as applied to corporations was discussed. It will be noticed that the courts have recognized such insurance to be advantageous.

The reasons why creditor's insurance is desirable are too obvious to require much comment. It secures a direct, specific, existing debt. It subserves the same purpose as a mortgage. And, in those states where the creditor is allowed to keep the policy alive even after the debt has been paid and is allowed to collect and retain the whole face of the policy, it possesses an additional and legitimate speculative advantage.

Every reason which may be advanced for taking out corporation insurance applies with equal or greater force to partnership insurance. In addition, there are many arguments in favor of the latter insurance which apply not at all to the former. This difference arises from the difference in the nature of the two forms of business organization.

A corporation has two main characteristics which make the business world look upon it with much favor. The first is the non-liability of the stockholders in any personal way for the corporation's obligations. The second is the continued existence of the corporation in spite of the death or withdrawal of its stockholders or officers. All may die, the stock may change hands any number of times, but the corporation is in legal theory a distinct entity, a legal person, and it continues to live.

On the other hand, a partnership possesses neither of the above characteristics. Although, for business purposes, the partners often look on the partnership as something distinct and apart from the individuals composing it, yet, in the eyes of the

\footnotetext{
${ }^{29}$ Vance On Insurance, p. 145 . To same effect see Note in 56 L. R. A. 585 , in which the writer admits the paucity of direct authority, but takes the view that consent should be held necessary on grounds of public policy. Some States require consent by statute. See Vol. 3 Va. Code, p. 6ro, requiring "knowledge or consent."
} 
law, this is not so. The law knows no such person, or entity, as a partnership. The name is simply a convenient designation for a coöperative and intimate form of business relationship in which there exists a mutuality of ownership, a community of interest, and a oneness in responsibility. Each partner is the agent of the other, with power to place upon the other obligations, with power to wreck the business. So, during the life of the partnership, there is an element of personal trust, personal reliance, and business intimacy about the relation which does not exist with respect to corporations. For example, not only the partnership assets, but every cent of the private individual property of each partner, is liable to the partnership creditors, and this though the obligation may have been contracted by one of the partners only without the other's knowledge or consent. Then, again, a partnership is automatically brought to a close by operation of law upon the happening of certain common and inevitable events. It can only live as long as all of the partners live. Its existence ceases if a partner, while alive, sells his stock and withdraws. And there is no way to keep a partner from quitting if he wishes to do so. It is true that by an agreement between the partners, or by the will of one of the partners, it may be provided that the business shall go on after a death. But, in legal contemplation, this is in every case a new partnership. It is thus seen that every partnership is necessarily and inevitably a creature of short life. It has only as long to live as all partners keep alive. It may meet its death at any time by the act of one in selling out, by his misconduct rendering a further continuance of the business impossible, his bankruptcy, his lunacy, or because the object for which the partnership was formed has become impossible.

Of course, the main embarrassments incident to a dissolved partnership arise when one of the partners dies. But the necessary readjustment which must follow upon the withdrawal of a living partner may prove to be a serious inconvenience and loss. A new partnership must be formed. This may be done in a mutually agreeable manner if there is no friction between the remaining members of the firm and the outgoing partner. On the contrary, if the retiring partner sells his interest to some person who does not care to have the business go on and to participate in it, such purchaser may call for an accounting and have the business wound up. Insurance on the life of a partner in such a case will not yet have matured. He is yet alive. But, 
even then, it may be a valuable asset, and according to the weight of authority it will not lapse but the remaining partners may keep it up and collect it as firm assets whenever the insured dies. They had an insurable interest in the insured's life when they took the policy out, and the subsequent loss of interest does not invalidate the insurance. But the most frequent event which causes trouble and loss to a partnership is the death of one of the partners. And this is the case where, if there is insurance on that partner's life, it is at once collectable and realizable as an asset, as ready money, to keep off trouble and to prevent loss.

If the survivors buy out the interest of the dead partner, this takes ready money. If they have not this money, then the only alternative is to wind up the partnership. The reason for this is that the dead partner did not own any specific part of the firm property which might be turned over to his representatives. His interest is only what remains as his share in money after the firm debts have been paid, the accounts between the partners and the firm settled, and the stock sold.

Moreover, such sale would ordinarily have to be a public sale. The remaining partners would usually not be permitted to buy in his share privately. The courts will, under some circumstances, permit this, but there must first be a full accounting and settlement to determine just what the interest of the dead man is, and an agreement by his administrator or executor to sell; and the courts will scrutinize such transactions with jealous care. Suppose, again, that the firm has entered into a contract. It may have relied primarily upon the dead partner to perform the contract. His death makes this impossible. Yet his death does not absolve the surviving partners from the obligation to perform the contract. So, a partnership, and each member thereof, is liable for a tort committed by any member of the partnership in the partnership business, and if one of the partners dies that does not keep the surviving partners from being responsible, even though the dead man is the one who actually committed the tort:

The death of the partner does not put off for any period the right of his administrator or executor to sue the survivors for an accounting, nor the right of the firm creditors to at once go against the surviving partners for any debt that is due. But generally, by statute, no debt is required to be paid by the administrator or executor of the deceased partner until a more 
or less extended period has elapsed after his qualification as such administrator or executor.

Upon the dissolution of the partnership by death of a partner, title to the personal assets vests in the surviving partners as trustees to wind up the business. It is the surviving partners' duty to collect all claims and pay all debts and dispose of the firm property to the best advantage, either as a whole, or in parcels, as he deems best; and it is both his right and duty to wind up the business as soon as possible, and, though he may continue it for a short time to enable him to dispose of the firm property, he cannot continue it indefinitely without the consent of the representatives of the deceased partner. He is strictly accountable for the firm property. He is not entitled to compensation for ordinary services in winding up the partnership business, though he is entitled to reimbursement for necessary expenses. ${ }^{30}$

All of the above considerations constitute strong practical reasons for holding partnership insurance valid, as well as a demonstration of its desirability as a prudent business investment.

R. W. WITHERS.

TAMPa, FIORIDA.

"Didlake v. Roden Grocery Co., I6o Ala. 484, 49 So. 384. 